MATERIALITY IN FINANCIAL REPORTING

An Integrative Perspective 
MATERIALITY IN FINANCIAL REPORTING

An Integrative Perspective

BY

FRANCESCO BELLANDI

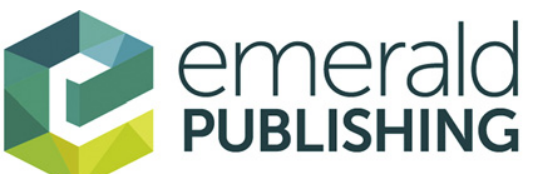

United Kingdom - North America - Japan India - Malaysia - China 
Emerald Publishing Limited

Howard House, Wagon Lane, Bingley BD16 1WA, UK

First edition 2018

Copyright (C) 2018 Emerald Publishing Limited

\section{Reprints and permissions service}

Contact: permissions@emeraldinsight.com

No part of this book may be reproduced, stored in a retrieval system, transmitted in any form or by any means electronic, mechanical, photocopying, recording or otherwise without either the prior written permission of the publisher or a licence permitting restricted copying issued in the UK by The Copyright Licensing Agency and in the USA by The Copyright Clearance Center. Any opinions expressed in the chapters are those of the authors. Whilst Emerald makes every effort to ensure the quality and accuracy of its content, Emerald makes no representation implied or otherwise, as to the chapters' suitability and application and disclaims any warranties, express or implied, to their use.

\section{British Library Cataloguing in Publication Data}

A catalogue record for this book is available from the British Library

ISBN: 978-1-78743-737-1 (Print)

ISBN: 978-1-78743-736-4 (Online)

ISBN: 978-1-78743-843-9 (Epub) 
To Anna, constant presence and support 


\section{Contents}

List of Figures $x i x$

About the Author $\quad x x v$

Preface $\quad x x v i i$

Part I. Introduction and Background 1

Main Focus of Part I 2

1. Why Does Materiality Matter in Financial Statements? 2

2. Powerful and Dangerous 3

3. The Disclosure Framework 4

4. The Disclosure Initiative 5

5. The Disclosure Effectiveness Initiative 6

6. Objectives of the Book 7

Part II. Conceptual Bases of Materiality 9

Main Focus of Part II 10

1. Materiality in the Conceptual Frameworks 10

1.a. The Objective of Materiality 10

1.b. Level of Interaction in the Conceptual Frameworks 10

1.c. A Pervasive Concept or a Qualitative Characteristic? 11

1.d. Is Materiality a Constraint? 15

1.e. Interaction with Qualitative Characteristics of Accounting Information $\quad 16$

1.f. Materiality versus Relevance 16

1.g. Entity Specificity 20

1.h. Materiality versus Reliability and Faithful Representation $\quad 22$

1.i. Completing the Picture: Materiality versus

1.j. Materiality versus Understandability 25 
1.k. Does Prudence or Neutrality Affect Materiality?

1.1. The Link to Recognition in the Conceptual Frameworks

1.m. Cost/Benefit Constraint versus Materiality 30

1.n. Impracticability versus Materiality 30

1.o. Significance 31

2. Definitions of Materiality 33

2.a. Can a Definition of Materiality Be Given? 33

2.b. Summary of Definitions 39

2.c. US Supreme Court's Definition 39

2.d. FASB (1985), CON 2

2.e. SEC Rules and Regulations 41

2.f. Common Law 43

2.g. IASB Framework 43

2.h. Common Conceptual Framework 43

2.i. The International Financial Reporting Standards $\quad 44$

2.j. Auditing Standards $\quad 45$

2.k. COSO Framework 45

2.1. AccountAbility 46

2.m. Integrated Reporting $\quad 46$

2.n. WRI and WBCSD 46

3. Attributes of Materiality 47

3.a. Subject Matter 47

3.b. What Is an Item? 47

3.c. An Item versus Its Content 48

3.d. Omissions or Misstatements 49

3.e. Material Disclosures of An Item versus Its Required
Disclosures

3.f. Materiality Test from Users' Perspective 50

3.g. Materiality Test Contrasted with the Objective of
General-Purpose Financial Statements

3.h. Materiality Test from the Standpoint of Objective Metrics 52

3.i. Addressees of Test 52

3.j. Reasonable Investor and Reasonable Person 52

3.k. Clusters versus Individuals 53

3.1. Primary versus Intended versus Other Users 53

3.m. Stakeholders versus Users 54

3.n. Assessor 55

3.o. Degree of Likelihood 55

3.p. Understanding Influence versus Influencing 57

3.q. Degree of Magnitude 59

3.r. Context 59 
3.s. Degree of Specificity $\quad 60$

3.t. Time Horizon 60

Solutions and Recommendations 61

$\begin{array}{ll}\text { Conclusion } & 67\end{array}$

Part III. Actors and Models of Materiality 69

Main Focus of Part III 70

1. Uses and Effects of Materiality 70

1.a. Is Materiality Exclusively a Legal Concept? $\quad 70$

1.b. Are Legal and Accounting Definitions of Materiality Incompatible? $\quad 71$

1.c. Practical Interactions of Legal and Accounting Concepts of Materiality 73

1.d. The Different Nature of an Accounting Concept of Materiality 74

1.e. The Quest for an Accounting Definition of Materiality 75

1.f. Materiality in Audit versus in Financial Statements 76

1.g. Other Uses of Materiality by Auditors 77

1.h. Materiality as a Managerial Concept $\quad 79$

2. Who Decides about Materiality? 79

2.a. Who Allows Materiality? 79

2.b. Who Uses Materiality? 80

2.c. Who Decides Materiality? 80

2.d. Who Assesses Materiality? 81

3. Models of Materiality 82

3.a. Do We Need a Framework of Materiality? 82

3.b. A Positive versus a Negative Concept 82

3.c. A Discrete versus a Continuous Notion 83

3.d. Different Disclosure Regimes 85

3.e. Simulating User Decision Model 86

3.f. Probability/Magnitude Mapping $\quad 86$

3.g. Severity of Deviancies 90

3.h. Range of Fluctuation $\quad 91$

3.i. Opportunity Loss $\quad 91$

3.j. Statistical Use of Information 91

3.k. Doctrine of Differential Disclosure 92

3.1. Expanded Dimensions of Materiality 95

3.m. The Flexibility Zone 97

3.n. Eyes of Management versus Eyes of Investors 98

3.o. The Ownership Triangle 100

3.p. Active versus Passive Role 101

3.q. The Sender-Receiver Distortion 102 
3.r. U-Materiality 103

3.s. Objective versus Subjective Determination 103

3.t. Materiality as a Planning Tool 104

3.u. Consensus Materiality 104

3.v. Adjustment Method 105

3.w. From Materiality to Materiality Determination Process 106

3.x. Qualitative Factors 106

3.y. Zero Materiality 107

Solutions and Recommendations $\quad 107$

Conclusion 112

Part IV. Application of Materiality 113

Main Focus of Part IV 114

1. Materiality Applied to Recognition and Measurement 114

1.a. Does Materiality Apply to Recognition and Measurement? 114

1.b. Inapplicability by Analogy 115

1.c. De Minimis 115

1.d. Significant Accounting Policies 115

1.e. Accounting Policies with Immaterial Effects 117

1.f. Scope of a Change in Accounting Policies 117

1.g. Materiality in Disclosing Voluntary Changes in
Accounting Policies

1.h. Materiality in Disclosing Involuntary Changes in Accounting Policies 118

1.i. The Case of Accounting Errors 119

2. Materiality Applied to Presentation and Disclosure 120

2.a. Does Materiality Apply to Presentation and Disclosure?

2.b. An Item versus Information of An Item 122

2.c. Required Disclosure of Immaterial Information 122

2.d. Allowed Disclosure of Immaterial Information 123

2.e. The Disclosure Overload Debate 124

2.f. Obscuring Material Information 125

2.g. Minimum Set of Required Disclosures 126

2.h. Classification 127

$\begin{array}{ll}\text { 2.i. Interaction of Aggregation and Disaggregation of } & \\ \text { Information } & 128\end{array}$

2.j. Top-down Model of Disaggregation in the Financial Statements 129

2.k. Bottom-up Model of Aggregation in the Financial Statements 
2.1. Classes of Aggregation

2.m. Alternative Model of Aggregation in the Financial Statements

2.n. General Models of Disaggregation for Disclosure Purpose

2.o. Review Assessment

2.p. Quality of Disclosure

2.q. Material Items

2.r. Disclosure Objectives 139

2.s. Gains and Losses 140

2.t. Effect of Measurement Bases 140

2.u. Third Statement of Financial Position 141

2.v. Rounding 141

2.w. When Required Disclosure Is Not Enough 142

3. Materiality Applied to Management Commentary 143

3.a. Management Commentary versus the Notes 143

3.b. Views of Materiality in Management Commentary 144

3.c. Material Known Trends or Uncertainties in SEC's MD\&A

3.d. Material Changes 149

3.e. Critical Accounting Estimates in MD\&A 149

3.f. Immaterial Information in MD\&A 150

3.g. Segment Analysis 150

3.h. Layered Disclosure 151

4. Does Materiality Apply to Bookkeeping? 151

4.a. Bookkeeping versus Financial Statements:

A Separate Perspective

4.b. Bookkeeping versus Financial Statements:

An Integrated Perspective

4.c. The Direct Impact on Financial Statements of Bookkeeping Errors

4.d. The Indirect Impact on Financial Statements of Bookkeeping Errors

4.e. The Delicate Link to Intentional Immaterial Errors 154

4.f. Immaterial Misstatements versus Bookkeeping Errors 155

4.g. Can Immaterial Bookkeeping Errors Be Left Uncorrected?

4.h. Does Materiality Apply to Bookkeeping? 156

4.i. Reasonableness versus Materiality 156

4.j. Legal Implications 157

4.k. Should Accountants Care of Materiality at All? 158

5. Materiality in Auditing 159

5.a. Audit Definition of Materiality 159 
5.b. Definition of Material Misstatement 160

5.c. The Risk of Material Misstatements and Assertions 161

5.d. Relationship between Audit Risk and Materiality 162

5.e. Iteration of Materiality and Inherent Risk 165

5.f. Second-Guessing Management's Determination of Users' Needs

166

5.g. Timing of Auditor's Consideration of Materiality 166

5.h. Undetected, Identified, Uncorrected, and Corrected Misstatements

5.i. How Materiality Affects Auditors' Responses to Misstatements

5.j. How Materiality Affects Auditors' Responses to Fraud 169

5.k. How Materiality Affects Auditors' Responses to Illegal Acts

5.1. Communications with the Management, Internal Auditors, and Audit Committee

6. Materiality Applied to Internal Control Over Financial Reporting

6.a. Internal Control over Financial Reporting versus Audit 172

6.b. Materiality and Technical Classifications of Internal Control Deficiencies in SOX

6.c. Materiality and Internal Control Deficiencies in COSO Framework

6.d. Materiality in PCAOB Audit Standard for ICOFR 175

6.e. Definition of Risk 175

6.f. Risk Tolerance 176

6.g. Risk Appetite 177

6.h. Risk Appetite and Risk Tolerance in the Context of Corporate Guidance Systems

6.i. Interlock of Risk, Risk Appetite, Risk Tolerance, and Precision of Internal Controls

6.j. Relationship between Risk Tolerance and Materiality 180

6.k. Planned Materiality versus Risk Tolerance and Performance Materiality

6.1. Relationship between Risk Tolerance and Precision of Controls

6.m. Inherently Imprecise Controls

6.n. Other Drivers of the Precision of Controls

6.o. The Importance of Immaterial Misstatements in ICOFR

6.p. Documentation of Determination of Immateriality 185

6.q. Role of Materiality in Testing ICOFR 185

6.r. Management Review Controls 186 
$\begin{array}{lll}\text { Part V. Assessing Materiality } & 199\end{array}$

Main Focus of Part V 200

1. Types of Assessment and Professional Judgment 200

1.a. Quantitative versus Qualitative Criteria 200

1.b. Is Quantitative an Assurance? 202

1.c. Is Magnitude Exclusively a Quantitative Concept? 202

1.d. What Is the Meaning of Qualitative? 203

1.e. When a Qualitative Assessment Is Always Required 204

1.f. When a Fact Is Always Material 204

1.g. Management Discretion 208

1.h. Auditor and Other External Professional Judgment 210

1.i. How Can the Management Judgment Be Professional? 211

1.j. What Is the Scope of Professional Judgment? 212

1.k. Who Is a Professional Judge? 213

1.1. When Is the Judgment Process Professional? 213

1.m. Documentation of Judgment 214

1.n. How to Evaluate Judgment Reasonableness? 214

1.o. Changes in Judgment and Reassessment 216

2. Quantitative Thresholds of Materiality 217

2.a. Thresholds for Whom? 217

2.b. Role of Quantitative Thresholds 217

2.c. The Case of an Absolute Dollar Amount 218

2.d. When a Relatively Small Misstatement May Be Material

2.e. When a Large Misstatement Can Be Immaterial 219

2.f. Performance Materiality 221

2.g. The Adjustment Method 223

2.h. Process Analysis of Materiality 223

2.i. Should the Management Use Materiality 223

3. Levels of Application of Materiality 224

3.a. The Concept of Whole Financial Statements 224

3.b. Periods of Whole Financial Statements 225

3.c. Materiality at Lower Levels 225

3.d. Consolidated versus Entity or Separate Financial
Statements

3.e. Component Materiality 227

4. Benchmarks 231

4.a. Common Benchmarks 231 
4.b. Relative versus Absolute Measures 232

4.c. Rules of Thumbs Used in Practice 232

4.d. Choosing Benchmarks 234

4.e. Normalizing Benchmarks 235

4.f. Deciding Percentages 236

4.g. Volatility 236

4.h. Industry Type 237

4.i. Capital Structure 237

4.j. Company Life Cycle 238

4.k. Pervasiveness 238

4.1. Degree of Aggregation 239

5. Comparative Information 239

5.a. Basic Period in Focus 239

5.b. Materiality in Prior Period 240

5.c. Corresponding Figures versus Comparative Financial Statements Approach 240

5.d. Third Statement of Financial Position 243

5.e. Materiality in Future Periods 243

5.f. Uncorrected Immaterial Misstatements Adding Up to Materiality in the Current Period 244

5.g. Effect of Changes of Materiality Benchmarks 250

5.h. Effect of Misstatement of Comparative Information 250

5.i. Counterbalancing and Noncounterbalancing Misstatements 251

5.j. Structure of the Notes 252

5.k. Effect on Financial and Forensic Analysis 252

6. Estimates 253

6.a. Risk of Material Misstatement of an Accounting Estimate

6.b. Inherent Level of Imprecision of an Accounting Estimate

6.c. The Linkage between Estimation Uncertainty and Materiality 254

6.d. Judgmental Misstatements 256

6.e. The Linkage between Inherent Imprecision and Misstatements 257

6.f. Management Bias 258

6.g. Effect of Materiality on Changes in Estimates 259

6.h. Linkage between Materiality and Sources of
Estimation Uncertainty

6.i. Critical Accounting Estimates 260

6.j. Effect on Reliability of Materiality of a
Misstatement of Estimate 
7. Individual versus Cumulative Misstatements 261

7.a. Analysis at Individual Item Level 261

7.b. Analysis at a Cumulative Level 262

7.c. Offsetting Misstatements 262

7.d. Aggregation Technique and Absolute Value 263

7.e. Trends and Ratios 263

8. Verification 264

8.a. Assessing Decisions 264

8.b. Documentation 265

8.c. Approaches to Verify Materiality Ex Post 265

8.d. The Implication in Terms of Accounting Changes 266

8.e. Methods to Assess Estimates 267

9. Immaterial Misstatements 267

9.a. Does GAAP Really Not Apply to Immaterial Items? 267

9.b. Are Misstatements of Immaterial Items Errors? 269

9.c. Intentional Immaterial Misstatements 269

9.d. Does Intention Make a Misstatement Always Material? 270

9.e. How to Judge Intentions? 271

9.f. The Difference between Achieving a Particular Presentation and Influencing Users 271

9.g. Investigating the Objective Element 272

9.h. A Policy to Ignore Immaterial Misstatements 272

9.i. Are Immaterial Misstatements Relevant to an Audit? 273

9.j. Material Effect of Accumulation of Immaterial Errors 273

9.k. Correction of Immaterial Errors 274

9.1. Tone from the Top 275

9.m. Legal Consequences 275

9.n. Summary of Treatment of Errors 275

10. Assessing Materiality in Interim Reporting 277

10.a. Reference Period of Materiality under IFRS 277

10.b. Reference Period of Materiality under US GAAP 278

10.c. Materiality in Interim Reporting for Correction of Errors

10.d. Materiality in Interim Reporting for Changes in Estimates and Changes in Accounting Policies 279

10.e. Relationship between Materiality to Interim and to Annual Financial Statements 280

10.f. Relationship between Estimation Uncertainty and Materiality in Interim Periods 281

10.g. Materiality for the Condensed Format of Interim Financial Statements 283

10.h. Audit Considerations 283

10.i. Interim Periods in MD\&A 284 
11. Assessing Materiality in Segment Reporting

Solutions and Recommendations 287

Conclusion 300

Part VI. The Materiality Determination Process 301

Main Focus of Part VI $\quad 302$

1. Processes and Methods 302

1.a. Linkage to the Judgment Process 302

1.b. Frameworks to Determine Materiality 302

2. Accounting-derived Approaches 303

2.a. The Qualitative Factors 303

2.b. The IASB's Four-Step Approach 303

3. Audit-derived Approaches 304

3.a. Audit Procedures 304

3.b. Audit Red Alerts 304

3.c. Materiality Benchmark Selection 310

3.d. Analytical Procedures 311

4. Risk-derived Approaches 311

4.a. Risk-Level Graphs 311

4.b. Heat Maps 311

5. Approaches Derived from Larger Frameworks 312

5.a. Materiality Determination in Integrated Reporting 312

5.b. Materiality Determination in AA1000 313

5.c. The Materiality Matrix 314

5.d. Five-Part Materiality Test 315

5.e. Significance/Influence Matrix 315

5.f. The Materiality Map 316

6. Disclosure of the Materiality Process 316

6.a. The Integrated Reporting Disclosures of the Materiality Process 316

6.b. The GRI Disclosures of the Materiality Process 317

7. Model Disclosures of Material Matters 317

7.a. General Disclosures in Accounting Standards 317

7.b. General Disclosures in Audit Standards 318

7.c. Disclosure of Material Matters in Integrated Reporting 319

7.d. Disclosure of Material Aspects in Sustainability Reporting 319

7.e. ITAC Principles-based Disclosures $\quad 320$

Solutions and Recommendations $\quad 320$

Conclusion 323 
Part VII. Where Standard Specifically Require Materiality Judgments

Main Focus of Part VII

1. Is Materiality Standard-Specific? 326

2. What Standards Say Users Want 326

3. The Notion of Inconsequential or Perfunctory 340

4. Materiality Applied to Specific Unit of Account 341

4.a. Materiality to Assess Performance Obligations 341

4.b. Materiality of a Financing Component 341

4.c. Materiality of a Customer Option 341

5. Related Parties 341

6. Materiality Applied to Specific Items or Circumstances 345

Solutions and Recommendations 345

Conclusion 346

Part VIII. Accounting Materiality in the Real World 347

Main Focus of Part VIII 348

1. The Materiality Paradox 348

2. Improvement of the Effectiveness of Financial Statements: The Standard-Setters' View 348

3. Behavioral Issues 349

4. Is There Something Missing? 350

5. Materiality Comments on SEC Staff IFRS Reviews 351

6. Typical Materiality Abuses by Management 354

6.a. Uses and Misuses of Materiality 354

6.b. Failure to Disclose 355

6.c. Below Materiality Threshold 355

6.d. Setting Materiality High 356

6.e. Ignoring Aggregation Risk 357

6.f. Aggregated Benchmarks 357

6.g. Offset 357

6.h. Static versus Dynamic Benchmarks 358

6.i. Income Statement Orientation 358

6.j. The Presentation versus Disclosure Game 359

6.k. The Change in Materiality Game 360

6.1. Undue Cost or Effort or Impracticability 360

6.m. Contra-Asset and Provision Items 360

6.n. Income Shifting 361

6.o. Unbundling Misstatements 361 
6.p. Statements Were Audited 362

6.q. Absolute Amounts 363

6.r. Too Difficult to Understand 364

6.s. Too Far in Time 364

6.t. Agency Conflicts 365

6.u. Management Commentary 365

6.v. Watering Information 366

6.w. Reclassifications and Continuous Restatement 366

6.x. Change in Judgment 367

6.y. Entity's Circumstances Are Different 368

6.z. Focus on Consolidated Financial Statements 368

6.aa. Delegation to a Service Organization 369

6.bb. Shooting a Moving Target 369

6.cc. Persistent Behaviors 370

6.dd. Manual Adjustments $\quad 371$

6.ee. Incorrect Bookkeeping $\quad 371$

Solutions and Recommendations 371

$\begin{array}{ll}\text { Conclusion } & 372\end{array}$

References 373

$\begin{array}{ll}\text { Index } & 397\end{array}$ 


\section{List of Figures}

\section{Part II}

Figure 1 Qualitative Characteristics under the IASB (1989) IASB Framework (reframed to compare with the FASB, 1985, CON 2). . . . . . . . . . . 12

Figure 2 Qualitative Characteristics under the Common Conceptual Framework (reframed to compare with the FASB, 1985, CON 2). . . . . . . . . . . 13

Figure 3 Qualitative Characteristics under the IPSAS Framework (reframed to compare with the FASB, 1985, CON 2). . . . . . . . . . . . . . . . . . . . . 14

Figure 4 Relevance and Materiality in FASB (1985), CON 2. 17

Figure 5 Relevance and Materiality in the IASB (1989), IASB Framework. . . . . . . . . . . . . . . . . . 18

Figure 6 Relevance and Materiality in Integrated Reporting. . . . . . . . . . . . . . 19

Figure 7 Reliability and Materiality in FASB (1985), CON 2.22

Figure 8 Reliability and Materiality in the IASB (1989), IASB Framework. . . . . . . . . . . . . . . . . . . 23

Figure 9 Relationships between Materiality, Relevance, Completeness, and Reliability in FASB (1985), CON 2. . . . . . . . . . . . . . . . . . . . . . . 24 
Figure 10 Relationships between Materiality, Relevance, Completeness, and Reliability in the IASB, 1989, IASB Framework. . . . . . . . . . . . . . . . 25

Figure 11 Comparisons of Definitions of Materiality.. . . . . 34

\section{Part III}

Figure 12 A Positive versus a Negative Concept of Materiality. . . . . . . . . . . 83

Figure 13 Graduation of Materiality. . . . . . . . . . 85

Figure 14 Material Information in Users' Decision Process. . 87

Figure 15 Multiplying Risk-Level Graphs. . . . . . . . . . . 88

Figure 16 Decoupled Effect Risk-Level Graphs.. . . . . . . . 89

Figure 17 Single Effect Risk-Level Graphs. . . . . . . . . . . 89

Figure 18 Recognition versus Disclosure along the Likelihood Axis.. . . . . . . . . . . . . . . . 9 90

Figure 19 The Materiality/Disclosure Dilemma. . . . . . . . 94

Figure 20 Possible Dimensions of Materiality. . . . . . . . . 96

Figure 21 The Flexibility Zone. . . . . . . . . . . . . . . 97

Figure 22 Eyes of Management versus Eyes of Investors. . 98

Figure 23 The Ownership Triangle. . . . . . . . . . . . 100

Figure 24 Materiality as a Planning Tool. . . . . . . . . . . 104

Figure 25 Consensus Materiality. . . . . . . . . . . . . 105

\section{Part IV}

Figure 26 IFRS Disaggregation or Aggregation Model for Presentation and Disclosure. . . . . . . . . . 128

Figure 27 Materiality Dimensions for Disclosure.. . . . . . . 137

Figure 28 Disclosure Based on Disclosure Relevance. . . . . 137 
Figure 29 SEC's 1987 Approach to Forward-Looking Disclosure.. . . . . . . . . . . . . . 146

Figure 30 SEC's 1989 Approach to Known Trends or Uncertainties. . . . . . . . . . . . . . . . . . 147

Figure 31 Classification of Assertions.. . . . . . . . . . . . 161

Figure 32 Relationship between Audit Risk and Materiality.. 163

Figure 33 Examples of Effects of Materiality on Audit Risk. . 164

Figure 34 Interaction of Materiality and Inherent Risk. . . . 166

Figure 35 Second-guessing Management's Determination of Users' Needs. . . . . . . . . . . . . . . . . . 167

Figure 36 How Materiality Affects Auditors'

Communication. . . . . . . . . . . . . 169

Figure 37 Effects of Materiality on Auditor's Response to Fraud. . . . . . . . . . . . . . 170

Figure 38 Effects of Materiality on Auditor's Response to Illegal Acts. . . . . . . . . . . . . . . . . 171

Figure 39 Representation of Internal Control Deficiencies in Risk Maps. . . . . . . . . . . . . . . . . . . . . 174

Figure 40 Relationship between Risk Appetite and Risk Tolerance. . . . . . . . . . . . . 179

Figure 41 Interlock of Risk, Risk Appetite, Risk Tolerance, and Precision of Internal Controls. . . . . . . . . 179

Figure 42 Risk Tolerance as an Indirect Measure of Materiality. . . . . . . . . . . . . 181

Figure 43 Planned Materiality versus Risk Tolerance and Performance Materiality. . . . . . . . . . . . . . 182

Figure 44 Precision of an Internal Control. . . . . . . . . . . 182

Figure 45 Inherently Imprecise Controls. . . . . . . . . . . . 184

Figure 46 Role of Materiality in Testing ICOFR. . . . . . . . 186 


\section{Part V}

Figure 47 Small versus Large Misstatements Materiality. . . 221

Figure 48 Use of Performance Materiality to Assess Estimation Uncertainty.. . . . . . . . . . 222

Figure 49 The Use of Performance Materiality to Assess a Point Estimate. . . . . . . . . . . . . . . . . 223

Figure 50 Component versus Group Materiality. . . . . . . . 229

Figure 51 Effect on the Details of Comparative Information of Corresponding versus Comparative Approach.. 241

Figure 52 Disaggregation Based on the Corresponding Figure Approach. . . . . . . . . . . . . . . . 242

Figure 53 Disaggregation Based on the Comparative Financial Statements Approach. . . . . . . . . . . 243

Figure 54 Materiality of Prior Period Misstatements. . . . . . 247

Figure 55 Accumulation of Prior Period Errors in the Disclosure Initiative Tentative Model. . . . . . . . 250

Figure 56 Risk of Material Misstatement of an Accounting Estimate. . . . . . . . . . . . . . . . . . . . 254

Figure 57 Inherent Estimation Uncertainty. . . . . . . . . 255

Figure 58 Assessment of a Material Misstatement in an Estimation Range. . . . . . . . . . . . . . . . 257

Figure 59 Assessment of a Material Misstatement in a Point Estimate. . . . . . . . . . . . . . . 257

Figure 60 Likelihood/Magnitude Mapping Applied to Reliability. . . . . . . . . . . . 261

Figure 61 Summary of Treatment of Errors. . . . . . . . . . 276

Figure 62 Effect on Materiality and Audit Risk of the Degree of Estimation of Interim Amounts. . . . . . . . . . 282

Figure 63 Materiality Augmentation in Segment Reporting. . 286 


\section{Part VI}

Figure 64 Risk-Level Graph. . . . . . . . . . . . . . . . . . . 312

Figure 65 Significance/Influence Matrix. . . . . . . . . . 316

\section{Part VII}

Figure 66 What Standards Say Users Want. . . . . . . . . . 327

Figure 67 References to Materiality Triggering-Specific Actions. . . . . . . . . . . . . . . . 343 


\section{About the Author}

Francesco Bellandi, US CPA (Certified Public Accountant); CGMA (Certified Global Management Accountant); Dottore Commercialista (Italian Chartered Accountant); Diploma in International Financial Reporting from the ACCA (The Association of Chartered Certified Accountants, UK); Degree in Economics (summa cum laude), LUISS University; M.B.A., SDA Bocconi School of Business, Bocconi University; Diploma in Private Equity from the A.I.F.I. (Italy's private equity association).

Francesco Bellandi is a practitioner in US GAAP/IFRSs dual reporting. Named by the AICPA as a worldwide IFRS US GAAP Subject Matter Expert, he is a member of the AICPA, the NYSSCPA (New York State Society of Certified Public Accountants), the NYSSCPA's International Accounting \& Auditing Committee where he has chaired the IFRS and the FASB subcommittees. He has been an Editorial Review Board Member of The CPA Journal, New York, USA.

Francesco Bellandi is a forensic auditor. He has served as a board director, chief financial officer, and finance director in several multinational companies around the globe and contract university professor in Audit and in IFRS.

He has authored several publications, including two books published by Wiley \& Sons, 2012: The Handbook to IFRS Transition and to IFRS U.S. GAAP Dual Reporting and Dual Reporting for Equity and Other Comprehensive Income under IFRS and U.S. GAAP.

He can be reached at francesco_bellandi@yahoo.com or francesco. bellandi@dualgaap.com. 


\section{Preface}

For financial statement neophytes, materiality looks like a philosophical issue, thought to be of little importance to practitioners and financial statements preparers adept to hard life. Yet, most of the internal management battles for what to filter through the internal reporting layers and what and how to disclose it in the external financial statements run on the verge of materiality.

Experienced financial statements preparers know that much of the discussion at the top management and board levels is on what to or not to present and disclose, justified on the grounds of materiality, but often for some other reason indeed. Auditors know that unless they can prove that a misstatement is material, their bullet would be smoothed. And if they did uncover something, they would pray that it was immaterial. Forensic analysts are aware that when a company says that something is not material, this alone is a good reason to investigate what this statement is trying to conceal.

Materiality is a slippery issue. Being so difficult and tricky, the FASB appears determined not to search for its definition in an accounting context. Standard-setters must serve a large audience, from preparers to investors. But preparers, indeed, are also among their stakeholders. They must find some trade-off: accounting is not for scientists and cannot be so difficult to be impossible or excessively costly. So, preparers push for materiality, invoking users, but really do users invoke materiality? Is this license too wide? It depends on how sophisticated the glasses of readers are, and from what angle they are viewing the scene. What could seem 
a departure from GAAP may in essence be acceptable as - somebody heard the auditor saying - it is not material. In a win-win situation, proving immateriality may give apparent relief to management for light sins and on the other hands be a useful defense to auditors. Investors, at least the most sophisticated of them, and financial analysts would rather have more information, because they know how to decide what is material to them. Securities regulators are obviously stricter than standard-setters.

Take it to the limit, somebody may have said after the fact, that it was too an immaterial issue to be of interest to users, and so this statement would be used to prove that before the fact there was an intent of fraud. The Court may have to say the last word.

This book offers an integrated perspective of materiality from the different angles of accounting standards for annual, interim, and segment reporting (including IFRS, US GAAP and SEC Rules and Regulations), auditing standards (including US and international ones), internal control over financial reporting, management commentary, financial analysis and management control, forensic analysis, sustainability reporting, corporate responsibility, assurance standards, integrated reporting, and limited legal considerations.

Part I introduces the background, including the scenario of the current debate as part of the IASB's Disclosure Initiative, the FASB's Disclosure Framework and the SEC's Disclosure Effectiveness Initiative.

Part II contrasts the views of the accounting conceptual frameworks. It then compares the definition of materiality in different standards and contexts, to then draw a taxonomy of materiality and its attributes.

Part III reviews the uses and effects of materiality as an accounting, legal, audit, and managerial concept. It counterbalances the interests and positions of the various stakeholders involved, such as investors, preparers, standard-setters, auditors, regulators, financial analysts, and other users of the financial statements. It then capitalizes on the author's vast experience in industry to devise alternative and complementary models of materiality with their pros and cons. 
Part IV provides readers with interlinked guidance in accounting and audit about the extant requirements for the application of materiality to recognition, measurement, presentation and disclosure in the financial statements. It also expands to issues that are typical of management commentary. It informs about the complexities and subtle differences between financial statements and bookkeeping on the subject. Two full sections cover the application of materiality in auditing and in internal control over financial reporting, respectively.

Part V of the book goes into the details of how to assess materiality. It draws from a plethora of different disciplines to go to the essence of the very meaning and application of professional judgment and its multifaced aspects in specific scenarios and decisions. This section goes into practical guidance that rarely can be found on a such judgmental topic.

Part VI illustrates different approaches concerning the processes and methods that an entity can establish to determine materiality. Given the highly subjective nature of materiality assessments, proper processes, systems and methodologies are at the forefront of the recent and future developments in this area.

Part VII tackles specific issues of application of materiality. This section includes an illustration of SEC Staff comments on materiality in the review of Form 20-F of foreign private issuers and a checklist of specific accounting pronouncements relating to specific materiality decisions.

Part VIII of the book wraps up the whole content in showing how an experienced professional can handle discussions with management to uncover inappropriate schemes, manipulation tactics, if not frauds. 